\title{
Interventions in Addressing Gender Issues in the Classroom
}

\section{Gretchen Gaye C. Ablaza}

Benguet State University, Km5, La Trinidad, Benguet

gg.ablaza@bsu.edu.ph 09075102981

_Article History: Received: 11 January 2021; Accepted: 27 February 2021; Published online: 5 April 2021

\begin{abstract}
Gender equality is the number five agenda of the Sustainable Development Goal, where its primary goal is providing women and girls with equal access to education. Up to this day, students experience gender issues, inequality, and bias inside the classroom. This research looked into the extent of observation on gender issues inside the classroom to eliminate bias, discrimination, and to achieve a comfortable classroom environment. More specifically, this research aimed to develop an intervention to address gender and development issues in the classroom. A Quantitative method of research was implemented using descriptive statistics to analyze data. Questionnaire was used to answer the specific problems; interview was conducted to validate the results of the study. Random sampling technique identified the respondents of the study from selected colleges and universities in the Cordillera Region. The extent of intervention programs, policies, and activities for teachers are moderately observed.
\end{abstract}

Keywords: gender equality, gender issues, gender-fair education, bias, discrimination

\section{Introduction}

Over the last few decades, gender problems in the classroom have been on the international study agenda and are still a concern in the Philippines. There are more research on gender gaps in school attendance and academic achievement. (Jelas et al. 2014). Previous research work in the Philippines centered on gender equity in the standard of education in the areas of instruction al language, learning materials and teaching aids, textbooks, curricula, events and interactions, and management $\begin{array}{lllll}\text { of } & \text { (Morales assrooms. } & \text { et 2015). } & \text { A }\end{array}$ recent research highlighted the gendersensitive pedagogical activities of teachers in terms of presentation of subj ects, arrangement of learning experience, creation of didactic approaches and selection of learning assessments (Lualhati 2019). The purpose of this research is to analyze gender fair-education and non-sexist writing in the classroom, intervention programs, policies and activities for students, and intervention programs, and policies for teachers as viewed by students. Researches conducted on this topic are only a few, and none so far was done in the area of study as of this writing, as evidenced by literature.

Gender issues in the classroom limits the performance of women. More than twenty percent of women were illiterate in 44 countries. $\quad$ Likewise, parity enrolment rates in higher education often obscure low participation by both males and females. On average , $65 \%$ of girls and $66 \%$ of boys have enrolled in secondary education globally, and only $39 \%$ of women and $34 \%$ of men are actually enrolled in college or university. This reality demands more ambitious goals to boost the development of human capital — for both men and women (World Economic Forum 2018).

There were verbal reports by some students that they experienced teachers using harsh words, double meaning words, and "green jokes," inside the classroom. Some even reported that some teachers inject jokes in class having double meaning, and some students felt terrible and uncomfortable about it because of the jokes labeled as "green jokes." Some students even reported as harassed by their teachers through the use of words. Students did not dare write complaints or submit a report to individuals concerned due to fear

The significance of the study is to look into the gender communication issues experienced by students. It also would look into the intervention programs, policies and procedures, and activities to manage these gender issues for both students and teachers. The aim of this study was to examine the extent of observation of students on the 
application of gender perspectives by the teacher in the classroom. Specifically, it seeks to define student perspectives on their teachers in terms of genderfair education, gender intervention services, student policies and activities, and teachers ' services, policies and ac tivities for gender intervention

Gender and education

Social learning theory, as developed by Albert Bandura in the 1960s and applied it in gender development by Walter Mischel in 1966, recognizes the importance of imitation and modeling in the development of social behaviors.

The theory of social learning continued to recognize the importance of conventional concepts of educati on, but also recognized the key role modeling plays in social behavior development.As applied to gender develop ment, modeling, and observational learning, it refers to a person's ability to learn vicariously by watching other $\mathrm{p}$ eople engaging in gendertyped activities and experiencing the reactions (e.g., rewards or punishments) that these people receive from others (Miller, 2016). This theory is used in this study as students learn what they see inside the classroom. As such, teachers should be role models for students to have a positive influence.

Gender fair education involves the experiences, perceptions, and perspectives of girls and women as well as boys and men (Pimentel, 2014). These are the activities given by the teacher to the students. It also includes the words, terminologies, and strategies of teachers inside the classroom. Gender issues are the negative experiences of students inside the classroom on account of gender.

Current studies reported gender disparity among students. As examined by Morales (2015), gender biases in the science and mathematics classrooms are observed; female surgical trainees continue to experience gender bias (Barnes et al. 2019), and in the Philippines, the strategic gender issues to be addressed are as follows: boys are underperforming in key education indicators compared to girls; indigenous people (IP) also fall behind in enrolment data and experience discrimination; higher education degrees manifest marked gender segregation; gender biases and stereotypes remain and are embedded still in the curricula, instructional methods, materials, and learning media; women and girls continue to be vulnerable to sexual harassment and violence inside schools because of the lack of safe and gender-responsive teaching-learning environment (Pimentel, 2014).

Materials and Methods

Research Design

This study utilized descriptive design to examine the extent of observation of students on gender-fair education, programs, policies, and activities of students and teachers. It is the best design for the study because there is no manipulation of variables or search for cause and effect related to the phenomenon. It only describes what exists, determine the frequency with which it occurs, and categorizes the information (Salsa et al. 2007).

\section{Respondents}

The respondents of the study were 129 Bachelor in Public Administration Students of the Institute of Public Administration, Benguet State University, and 102 Bachelor of Criminal Justice Education students of the King's College of the Philippines, both in La Trinidad, Benguet, enrolled during the second semester SY 2016-2017. Random sampling technique was employed to determine the number of participants for this study. Using the Slovin's formula, there were 231 respondents. Of the 231 respondents, 161 were female, while 70 were male. Most of them belong to the 15-18 age group with a frequency of 115, followed by 19-22 age group with a frequency of 104, then the 19-22 age group with a frequency of 12, and the 27-30 age group with a frequency of 1.

\section{Instrumentation}

To obtain the needed data, the researcher utilized a modified questionnaire from various authors on gender. A sixitem survey adapted from Pimentel (2014) to answer gender-fair language, a seven-item survey from Thelma Kintanar (2005), on non-sexist writing, a fourteen-item questions for the intervention programs, policies, and activities, for students and, a ten-item questions for the intervention programs, policies, and activities for teachers 
were both taken from UNESCO. The researcher adapted these to conform to the needs of this study and to make it more suitable to the target respondents. After careful reviews of different literatures, the researcher came up with a total of 37-item questionnaire to reveal the respondents' assessment of the indicators mentioned.

To ensure the instrument's validity and reliability, the researcher sought the assistance of the two experts in the field of gender and development and statistician. The obtained .829 alpha coefficient suggests that the instrument was reliable. The study used the following mean ranges with their corresponding interpretations:

Scale Mean Ranges Verbal Interpretation

3.27-4.00 Very much observed $\quad$ (VMO)

2.52-3.26 Moderately observed (MO)

1.76-2.51 Slightly observed $\quad(\mathrm{SO})$

1.0-1.75 Least observed (LO)

\section{Data Collection}

The researcher solicited permission from the director and dean of both institute and department, as well as from the respondents. Upon authorization, the researcher duly consulted the secretary of the department for the questionnaire administr ation schedule. She directly circulated the questionnaire and collected it.

A short informal interview was conducted to the respondents to gather more information about the problems. Data collected were reviewed, assessed, rated, and processed by weighted average, level, and percentage. Accura te interpretations and analysis of the data allowed the researcher to develop strategies to improve the responsiven ess of geder sensitivity in the classroom.

Not included in this study is the comparison between the two groups of respondents and classroom observation due to time constraints. This study only looked into the perceptions of the students from the two schools but not the comparison.

\section{RESULTS}

This paper addresses three categories of findings: firstly, gender-related communication issues observed by learners; secondly, the extent of observation on the intervention programs, policies and procedures, and activities for students, and thirdly, the extent of observation on the intervention programs, policies and procedures, and activities for students.

Table 1 presents the gender-related communication issues as observed by learners. The table shows that respondents moderately observed gender-related communication issues in their classrooms, as evident in the computed average weighted mean of 2.84 with a descriptive equivalence of moderately observed. The data also reflects that students have equal right to speak in the classroom, obtaining the highest mean of 3.23 and a descriptive equivalent of very much observed. This was followed by everyone is encouraged to write their thoughts and feelings, with a mean of 2.99 and a descriptive equivalence of moderately observed.

Table 1 Gender-Related Communication Issues Observed by Learners

\begin{tabular}{|l|c|c|}
\hline Gender fair education (Marissa Castillo Pimentel) & Mean & DE \\
\hline $\begin{array}{l}\text { 1. } \\
\text { The instructor uses neutral expression rather than gender-specific ones ("police officer" } \\
\text { instead of "policeman," "chair" instead of "chairman" }\end{array}$ & 2.73 & MO \\
\hline $\begin{array}{l}\text { 2. } \\
\text { The instructor uses plural nouns and pronouns instead of singular, gender-specific } \\
\text { forms. ("Every student should read his syllabus at the beginning of the term." } \\
\text { Instead "Students should read their syllabi at the beginning of the term.") }\end{array}$ & 2.66 & $\mathrm{MO}$ \\
\hline 3. $\quad$ Everybody has an equal right to speak inside the classroom. & 3.23 & $\mathrm{VMO}$ \\
\hline $4 . \quad$ Everyone is allowed an opportunity to talk inside the classroom. & 2.91 & $\mathrm{MO}$ \\
\hline 5. $\quad$ Everyone is encouraged to write their thoughts and feelings. & 2.99 & $\mathrm{MO}$ \\
\hline $6 . \quad$ The teacher creates a gender-responsive teaching-learning environment & 2.90 & $\mathrm{MO}$ \\
\hline & & \\
\hline Non-Sexist Writing (Thelma Kintanar) & & \\
\hline
\end{tabular}




\begin{tabular}{|l|c|c|}
\hline $\begin{array}{l}\text { 1.Replace man with specific nouns or verbs that say explicitly what you mean (instead of } \\
\text { manpower, use human resources personnel) }\end{array}$ & 2.73 & MO \\
\hline 2.Use nouns that encompass both man and woman (instead of mankind use humanity) & 2.94 & MO \\
\hline $\begin{array}{l}\text { 3. In making general statements, add women (instead of Man is vulnerable use Women and } \\
\text { men are vulnerable) }\end{array}$ & 2.84 & $\mathrm{MO}$ \\
\hline $\begin{array}{l}\text { 4. Identify both men and women in the same way when it comes to profession or employment } \\
\text { (instead of stewardess, steward use flight attendant) }\end{array}$ & 2.43 & $\mathrm{MO}$ \\
\hline $\begin{array}{l}\text { 5.Represent women or men as occupying only specific jobs or roles: (Instead of "the } \\
\text { kindergarten teacher....she use "the kindergarten teacher...he) }\end{array}$ & 2.81 & $\mathrm{MO}$ \\
\hline $\begin{array}{l}\text { 6. Treat men and women in a parallel manner (President Ramos and Cory, use former } \\
\text { President Ramos and former President Cory) }\end{array}$ & 2.60 & $\mathrm{MO}$ \\
\hline Average Weighted Mean & 2.84 & $\mathrm{MO}$ \\
\hline
\end{tabular}

Legend:
3.27-4.00
2.52-3.26
1.76-2.51
$1.0-1.75$
(VMO)
(MO)
(LO)

Table 2 presents the extent of observation on the intervention programs, policies and procedures, and activities for students regarding gender-fair language. Results show that the respondents had moderate observation on the intervention programs, policies, and activities with a weighted mean of 2.63. The data reflects that the respondents moderately observed that seating arrangements, give an equal opportunity for both boys and girls to participate in class and interact with the teacher with a mean of 2.95. However, the data also reflects that students slightly observed that there is a clear policy on reproductive health in their institution as revealed by the mean of 1.99

Table 2 Intervention Programs, Policies, and Procedures, Activities for Students

\begin{tabular}{|c|c|c|}
\hline Student Activities & MEAN & DE \\
\hline 1. Students have attended gender sensitivity training. & 2.81 & MO \\
\hline $\begin{array}{l}\text { 2. Students have seminar or orientation on RA } 7877 \text { or the Anti Sexual harassment } \\
\text { law }\end{array}$ & 2.47 & MO \\
\hline 3. Students have seminars on handling intimate relationships & 2.71 & MO \\
\hline 4. Students have trainings on abusive relationships & 2.50 & MO \\
\hline \multicolumn{3}{|l|}{ School and Classroom Facilities (UNESCO) } \\
\hline 1. There are enough seats and seating space for both girl and boy students & 2.81 & MO \\
\hline $\begin{array}{l}\text { 2. Seating arrangements give an equal opportunity for both boys and girls to participate in } \\
\text { class and interact with the teacher and other students. }\end{array}$ & 2.95 & MO \\
\hline 3.Sufficient amount of light and fan/heating arrangements for both girls. & 2.63 & MO \\
\hline $\begin{array}{l}\text { 4. Clean drinking water in school is available and accessible for all students, including girls } \\
\text { and boys. }\end{array}$ & 2.65 & MO \\
\hline \multicolumn{3}{|l|}{ Teaching and Learning Materials (UNESCO) } \\
\hline 1. Each boy and girl have essential schoolbooks and other learning materials & 2.78 & MO \\
\hline $\begin{array}{l}\text { 2. Teaching and learning materials portray girls and boys of varying socio-economic and } \\
\text { religious backgrounds, including those with disabilities, with equal prominence, potential, } \\
\text { and respect. }\end{array}$ & 2.88 & MO \\
\hline 3. Materials and resources used by the students are free from gender stereotypes & 2.81 & MO \\
\hline \multicolumn{3}{|l|}{ Security and Health Issues of Students } \\
\hline 1. The school is close enough for all school-age boys and girls to walk to. & 2.75 & MO \\
\hline $\begin{array}{l}\text { 2. Both boys and girls are safe on their way to school. Services provided to ensure their } \\
\text { safety, such as transportation. }\end{array}$ & 2.67 & MO \\
\hline \multicolumn{3}{|l|}{ 3. In the school and on the way to/from school, girls and boys feel safe from } \\
\hline a. $\quad$ Bullying & 2.58 & MO \\
\hline b. Discrimination & 2.32 & SO \\
\hline c. Sexual Harassment & 2.10 & SO \\
\hline $\begin{array}{l}\text { 4. Girls who get pregnant are supported by the school, and they feel free to continue } \\
\text { schooling }\end{array}$ & 2.62 & $\mathrm{SO}$ \\
\hline 5. There is a clear policy on reproductive health & 1.99 & SO \\
\hline 6. Teachers and school officials are aware of existing laws on reproductive health & 2.88 & MO \\
\hline
\end{tabular}


Average Weighted Mean

Legend:

$3.27-4.00$

2.52-3.26

$1.76-2.51$

$1.0-1.75$
Very much observed

Moderately observed

Slightly observed

Least observed

Table 4 Intervention Programs, Policies and procedures, and Activities for Teachers

\begin{tabular}{|l|l|l|}
\hline & Mean & DE \\
\hline 1. Teachers have attended gender-sensitive training conducted by the school & 2.94 & MO \\
\hline 2. Teachers have training on gender fair instructional material. & 2.75 & MO \\
\hline 3. Teacher training on gender-fair language on instruction & 2.42 & MO \\
\hline 4. Teachers orientation on RA 7877 or Anti Sexual Harassment & 2.71 & MO \\
\hline 5. Teachers orientation on Magna Carta of Women & 2.68 & MO \\
\hline Gender-Sensitive Classroom & & \\
\hline $\begin{array}{l}\text { 1. Teachers value equally the learning ability of both female and male learners (girls/women, } \\
\text { boys/men) }\end{array}$ & 3.02 & MO \\
\hline $\begin{array}{l}\text { 2. Facilitate both female and male learners' abilities to learn and progress equally and develop } \\
\text { their potential to the fullest. }\end{array}$ & 2.81 & MO \\
\hline $\begin{array}{l}\text { 3.React cautiously to unfriendly and potentially gender-biased attitudes that learners may } \\
\text { demonstrate towards other female and male learners }\end{array}$ & 2.90 & MO \\
\hline 4. Help learners question these attitudes to prevent them from happening in the future. & 2.82 & MO \\
\hline 5. Call on or address both female and male learners a balance number of times. & 2.59 & MO \\
\hline $\begin{array}{l}\text { 6.Give both female and male learners equal opportunity to write on the writing board a fair } \\
\text { number of times and on all subjects. }\end{array}$ & 2.91 & MO \\
\hline $\begin{array}{l}\text { 7.Give both female and male learners equal opportunity to present their work or answers to the } \\
\text { class on the same regularity and for all subjects }\end{array}$ & 2.94 & MO \\
\hline $\begin{array}{l}\text { 8. Give similar duties to both female and male learning (example cleaning, mowing furniture, } \\
\text { etc.) }\end{array}$ & 2.79 & MO \\
\hline $\begin{array}{l}\text { 9. Support and encourage both female and male learners to be class leaders, possibly having one } \\
\text { female and one male as co-leaders. }\end{array}$ & 2.88 & MO \\
\hline $\begin{array}{l}\text { 10. Use materials that portray female and male characters in equal numbers and involved in } \\
\text { similar activities. }\end{array}$ & 2.92 & MO \\
\hline Average Weighted Mean & 2.81 & MO \\
\hline
\end{tabular}

\section{Legend:}

$3.27-4.00$

$2.52-3.26$

$1.76-2.51$

$1.0-1.75$
Very much observed

Moderately observed

Slightly observed

Least observed
(VMO)

(MO)

(SO)

(LO) 
FRAMEWORK for Gender Fair Education

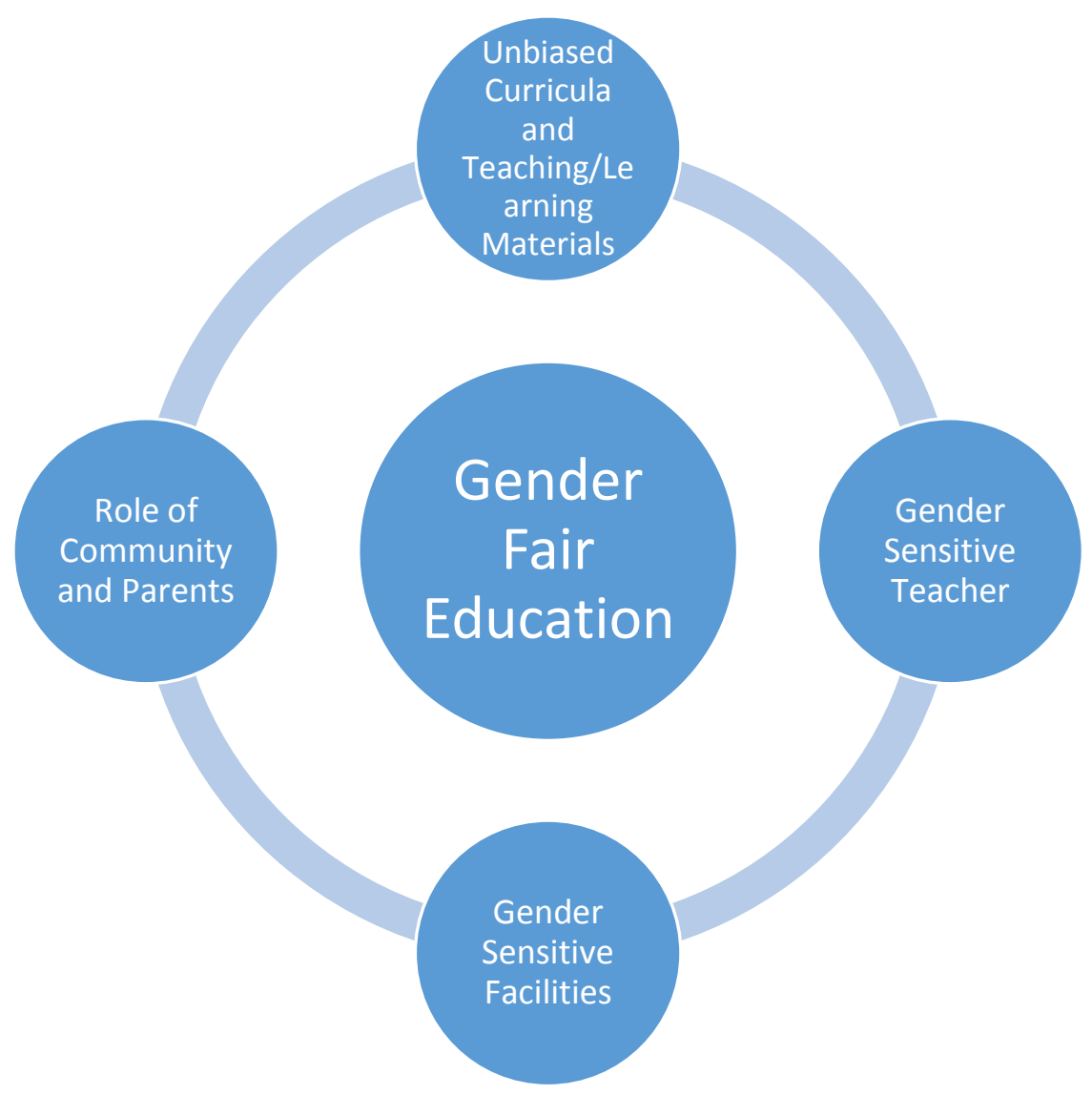

Figure 1. Framework for Gender Fair Education

\section{GENDER EQUALITY IN EDUCATION REQUIRES UNBIASED CURRICULA AND TEACHING/LEARNING MATERIALS}

To facilitate gender-fair education, instruction, curricula, and materials should be free from gender bias and promote equality in gender relations. How students perceive themselves and how they project their role in society is shaped to some extent by what they experience at school, including by how its representation in textbooks. As espoused by Bandura in his social learning theory, it recognizes the importance of imitation and modeling in the development of social behaviors.

Teaching/learning materials should portray female and male characters in equal numbers and involved in similar activities; if not, the teacher should try to call on learners and help them challenge stereotypes in the portrayal of female and male characters in the teaching/learning materials used. Display posters on the walls that portray female and male characters in equal numbers and involved in activities together.

\section{GENDER EQUALITY IN EDUCATION REQUIRES GENDER SENSITIVE TEACHER}

Aside from the influence of official curricula and materials, teacher practice in the classroom is shaped by their assumptions and stereotypes about gender, which in turn affects students' beliefs and learning. Teacher education can assist teachers in reflecting on and overcoming their biases. Formal initiatives in teacher education with a focus on gender should be observed. Teacher candidates should complete a mandatory course on gender, and to develop more gender-sensitive attitudes, preservice teachers may take a semester-long course on gender equity in education.

Promoting gender equality in education involves teachers having a classroom seating plan that enables both female and male learners to participate and have equal opportunities to learn. Provide guidance and 
counseling, if possible, as well as mentoring support to both female and male learners with regard to the continuation of their studies, job perspectives, or psycho-social needs. This support should be delivered in a gender-sensitive way so that both boys and girls do not choose stereotyped paths. Teachers should also seek advice on teaching methods that are more gender-sensitive from other teachers from the school head from the school inspector from the ministry's gender focal point from gender experts and attending formal training courses from parent-teacher associations, whenever relevant from NGOs, whenever relevant by his/her own means through selfstudy.

\section{GENDER-SENSITIVE FACILITIES}

Gender-sensitive facilities can help attain gender-fair education. Facilities include comfortable restrooms for girls, which include water and soap to wash hands. Secured schools and a healthy environment should be achieved and the accessibility of the school for both boys and girls. The school should be free from bullying, discrimination, sexual harassment. School and classroom facilities should be well-maintained and adequate number of functional latrines for both girls and boys. The school should have guidance and counseling programs and facilities. It should also include sexuality and reproductive health topics.

\section{ROLE OF COMMUNITY AND PARENTS}

In realizing gender-fair education, the help of community members and parents are vital. There should be a system of community funding. There should be an opportunity for community members and parents volunteering in the school. Donations should be open to the school, and fundraisers should support the school.

\section{Conclusion}

In sum, this paper has provided an insight into the many perplexing questions about gender-fair education and intervention. Research in gender issues in the classroom and the interventions has led researchers and educators to many more questions. A more in-depth analysis of how to achieve gender-fair education is necessary by understanding the experiences of learners, class observations, and comparison among schools.

\section{REFERENCES}

1. Jelas, Z. et al., 2014. Gender Disparity in School Participation and Achievement: The Case in

a. Malaysia. University. Kebangsaan Malaysia, Bangi 43600, Malaysia. 1877-0428 (c) 2014.

Published by Elsevier. (http://creativecommons.org/licenses/by-nc-nd/3.0/).

2. doi: 10.1016/j.sbspro.2014.04.387

3. Kintanar, T., 2005 Gender-Fair Language: A Primer. University Center for Women's Studies,

a. University of the Philippines, Diliman, Quezon City. Copyright 1998. University Center for Women's Studies

4. Lualhati, G., 2019. Gender Sensitizing: Examining Filipino Educators' Pedagogical Practices a. and Teaching Effectiveness Asia Pacific Journal of Multidisciplinary Research Vol. 7

b. No.1, 67-76. February 2019 P-ISSN 2350-7756 E-ISSN 2350-8442. www.apjmr.com CHED Recognized Journal ASEAN Citation Index

5. Miller, C., 2016. Gender Development, Theories Of.

a. https://www.researchgate.net/publication/315785215 Gender Development, Theories

6. Of Chapter - April 2016 DOI: 10.1002/9781118663219.wbegss590. Arizona State

a. University

7. Morales, M., et al. 2015 Exploring gender disparities in science and mathematics classrooms in a. the Basic education International Journal of Research Studies in Education 2016

8. July, Volume 5 Number 3, 39-58 @ The Author(s)/Attribution CC B DOI: 10.5861/ijrse.2015.1263 ISSN: 2243. ISSN: 2243-7703 Online ISSN: 2243-7711

9. OPEN ACCESS

10. Pimentel, M., 2014, Gender Fair Education (GFE): Teaching gender equality and non-sexist a. Learning. Program Coordinator Gender Fair Education Program Women and Gender Institute Miriam College 
11. Sousa, M. et al., 2007. An overview of research designs relevant to nursing: Part 1: Quantitative

a. $\quad$ research designs. Revista Latino-Americana de Enfermagem. On-line version ISSN 1518-8345 Rev. Latino-Am. Enfermagem vol.15 no.3 Ribeirão Preto June 2007 http://dx.doi.org/10.1590/S0104-11692007000300022

12. World Economic Forum., 2019. The Global Gender Gap Report. $91-93$ route de la Capite

13. CH-1223 Cologny/Geneva, Switzerland.E-mail: contact@weforum.org

14. www.weforum.org Copyright (C) 2018 by the World Economic Forum All rights

15. reserved. ISBN-13: 978-2-940631-00-1

16. United Nation., 2015.

a. https://www.undp.org/content/dam/undp/library/corporate/brochure/SDGs_Booklet_Web_En. pdf Accessed on June 28, 2016

17. UNESCO., 2017. A Guide for ensuring inclusion and equity in education.

a. UNESCO [50473], UNESCO. Assistant Director-General for Education, 2010-2018 (Qian Tang). ISBN: 978-92-3-100222-9 (print/pdf). 2017: CC BY-SA 3.0 IGO [6661]. book 